\title{
When an Event is Not an Event: The Curious Case of an Emerging Market
}

\author{
Utpal Bhattacharya ${ }^{1} /$ Hazem Daouk $^{2}$ / Brian Jorgenson ${ }^{3}$ / \\ Carl-Heinrich $\mathrm{Kehr}^{4}$
}

June 1998

\begin{abstract}
Shares trading in the Bolsa Mexicana de Valores do not seem to react to company news. Using a sample of Mexican corporate news announcements from the period July 1994 through June 1996, this paper finds that there is nothing unusual about returns, volatility of returns, volume of trade or bid-ask spreads in the event window. This suggests one of five possibilities: our sample size is small; or markets are inefficient; or markets are efficient but the corporate news announcements are not value-relevant; or markets are efficient and corporate news announcements are value-relevant, but they have been fully anticipated; or markets are efficient and corporate news announcements are value-relevant, but unrestricted insider trading has caused prices to fully incorporate the information. The evidence supports the last hypothesis.

The paper thus points toward a methodology for ranking emerging stock markets in terms of their "market integrity," an approach that can be used with the limited data available in such markets.
\end{abstract}

Keywords: Event study, insider trading, emerging markets

JEL classification: G14, G15

\footnotetext{
${ }^{1}$ Kelley School of Business, Indiana University, Bloomington, IN 47405. Email: ubhattac@indiana.edu

${ }^{2}$ Kelley School of Business, Indiana University, Bloomington, IN 47405. Email: hdaouk@indiana.edu

${ }_{3}^{3}$ Carreker-Antinori, 14001 N. Dallas Parkway, Suite 1100, Dallas, TX 75240. Email: bjorgenson@ carreker.com

${ }^{4}$ BankBetriebsWirtschaft, Kreuzberger Ring 21, D-65205 Wiesbaden, Germany. Email: ckehr@wiwi.unifrankfurt.de

* This paper began at the University of Iowa, was a work-in-progress in Mexico and Germany, and was completed at Indiana University. Our thanks go to Xuemin Yan, who painstakingly cross-checked all data, and to Michele Fratianni, Tom George, Craig Holden, Gur Huberman, Bob Jennings, S.P. Kothari, Bing Liang, Tim Loughran, Jegadeesh Narasimhan, Don Siegel, Pravin Trivedi and Anand Vijh for providing detailed comments. Seminar participants at the universities of Frankfurt and Heidelberg furnished critical feedback. The first author thanks the Center for Financial Studies at Frankfurt for its hospitality during the summers of 1996 and 1998. John Clarke (NY Fed), Kent Hargis (University of South Carolina) and Fernando Zapatero (ITAM, Mexico City) provided valuable institutional detail, and for this we are deeply indebted. All errors are our own.
} 


\section{WHEN AN EVENT IS NOT AN EVENT: THE CURIOUS CASE OF AN EMERGING MARKET}

Event studies are used to measure the impact of an economic event on firm value. Assuming that the event will be reflected in traded asset prices, these studies focus on how asset prices respond to information released during a public announcement of the event. ${ }^{1}$ An interesting debate, discussed in Fama (1997), rages on about the speed of stock price reaction to the information released during news announcements, on whether there is systematic over-reaction or under-reaction to information, and on whether the over-reaction or under-reaction is inexplicably large. Though there exist many such disagreements on the reaction of stock prices to information released during a public announcement, these disagreements arise in the first place because stock prices do react.

Is it possible to have a stock market where a firm's stock price does not react to firmspecific news announcements? Imagine an inefficient stock market, where stock prices do not reflect any value-relevant information. In such a stock market, stock prices will not react to corporate announcements. Or imagine an economy where corporations do not make valuerelevant news announcements. We should not see any reaction here, either. Or imagine an economy where the stock market is efficient and the news is value-relevant, but it is completely anticipated. ${ }^{2}$ In such an economy, there will be no surprise on the day of the announcement. Or imagine a stock market where insider trading prohibitions do not exist or, if they exist, are not enforced. In this market, the superior information of insiders may already have been incorporated

Ball and Brown (1968), and Fama, Fisher, Jensen, and Roll (1969) pioneered the classic event study methodology and, except for minor modifications (see Salinger (1992)), their methodology continues to be used in the numerous event studies published every year. Campbell, Lo and MacKinlay (1997) provide an excellent exposition of the event-study methodology in Chapter 4 of their book. McWilliams and Siegel (1997) discuss the many uses and abuses of this methodology in the social sciences.

In the period 1970 to 1979 , Huberman and Schwert (1985) document that 85 per cent of the news contained in a CPI announcement had been anticipated and was being reflected in the prices of Israeli indexed bonds. Like this paper, they also ask whether an announcement constitutes an event, and how much of an event. 
in stock prices through their trades. ${ }^{3}$ In that case, the public announcement would be news to everyone except the traders. In all the above four cases, the corporate news announcement is not really an event (if we define an event as a point in time where a lot of information is incorporated into stock prices). ${ }^{4}$

We provide an apparent example in this paper of a stock market where the stock price does not react to firm-specific news announcements. In this stock market, we find that abnormal returns in an event window, defined conventionally as the day before to two days after a firmspecific public news announcement, are not abnormal. Volatility, volume of trade and bid-ask spreads in the event window are not atypical either.

Why do firm-specific news announcements not affect stock prices in our example? If market inefficiency and/or value-irrelevant corporate news announcements are the reasons, no linkage is expected to exist between prices and information before or after the news announcement. No linkage is also expected if our sample size is small, and our econometric tests do not have enough power. We provide evidence against these three possibilities. A careful examination of the pre-announcement period reveals that information is being gradually impounded into stock prices. We should not be able to detect this if markets are inefficient, or the news announcements are value-irrelevant, or the power of our tests are small because of a small sample size.

Since our news announcements cover a variety of firm-specific episodes (abnormal earnings announcements, bankruptcy announcements, merger announcements, etc.) rather than 
just one kind of episode, we cannot employ the conventional technique of testing for a price runup or price run-down to show pre-announcement drift. ${ }^{5}$ Instead, we show this using two different types of tests.

The first series of tests document that the return volatility of A-shares (these are shares which only citizens may hold) unambiguously leads return volatility of B-shares (these are shares which foreigners can hold), suggesting that there is an information spillover from A-shares to Bshares. If this is so, considering that citizens may hold both type of shares and foreigners have ways to get around the legal restrictions, why is this not arbitraged away? This leads to our second series of tests. We show that, if bid-ask spreads are ignored, economically and statistically significant returns are to be made by utilizing simple technical trading rules that exploit this leadlag relationship, but if transaction costs are taken into account, the maximum return achievable is less than the risk-free return in this market. So the lead-lag relationship is not arbitraged away.

Could stock prices be insensitive to news announcements in our example because the public had fully anticipated them? If so, both A-shares and B-shares should have the same preannouncement price behavior. The fact that the prices of the A-shares lead the prices of the Bshares hints that insider trading rather than full anticipation by the public may be responsible for the insensitivity of stock prices to corporate news announcements. Another piece of evidence favoring the above conclusion is that at the time of the corporate news announcement, though both types of shares show little reaction, the reaction of the A-shares is even less than the reaction of the B-shares. So holders of the A-shares are less surprised by the announcement than holders of the B-shares.

The stock market we choose to present as an illustration is the Mexican Stock Exchange,

The reason we analyze all types of news announcements instead of just one type is because we do not have enough data points for a particular type. This problem of lack of data is endemic in emerging stock markets. As one objective of our paper is to progress towards a methodology for ranking emerging stock markets in terms of their "market integrity," it is clear that non-conventional econometric techniques have to be used to handle the paucity of data. See the concluding remarks of this paper for a fuller discussion. 
the Bolsa Mexicana de Valores (BMV). Why Mexico? There are several reasons for this choice. First, we wanted to study a stock market where undisclosed insider trading was a possibility, because that would be a market where the superior information of insiders would already have been incorporated in stock prices through their trades. From its inception to the period covered in this study, there has not been a single indictment, trial and/or conviction for insider trading in the BMV. Second, since share ownership in Mexico is segmented into various classes, it is possible to test for differential responses to corporate news announcements. Third, data are available for the Mexican stock market. For the purpose of this study, we needed and obtained daily share trading data and records of corporate news announcements of the most liquid stocks. Fourth, and finally, given that Mexico is a representative emerging market, it formed an ideal "pilot study" in our quest for a methodology for ranking emerging stock markets in terms of their "market integrity," a methodology that could be used by researchers and practitioners who do not have access to intra-day data that is available in more advanced stock markets.

Empirical research on international market segmentation - segmentation by ownership, by trading locations, or by voting rights - is a growth industry. A partial list of papers would include Jorion and Schwartz (1986), Alexander, Eun and Janakiraman (1988), Jayaraman, Shastri and Tandon (1993), Foerster and Karolyi (1993), Umlauf (1993), Bailey and Jagtiani (1994), Chan, Fong and Stulz (1995), Kleidon and Warner (1995), Stulz and Wasserfallen (1996), Forster and George (1996) and Domowitz, Glen and Madhavan (1997, 1998). Though each of the above papers focuses on a different issue, there is a central theme in this literature: the violation of the law of one price that results from exogenous or endogenous segmentation. Our paper, which belongs to this literature, attempts to document the different reaction of share prices in segmented markets to corporate news announcements. 
The paper is structured as follows. In Section I we give a brief background of the BMV, with particular emphasis on the enforcement of insider trading regulations and the types of shares being traded. The data are described in Section II. Section III presents numerous graphs documenting the impact on trading behavior, or the lack thereof, of corporate news announcements. In Section IV, we provide evidence suggesting that insider trading is responsible for the insensitivity of stock prices to corporate news announcements. Section V concludes. Here we summarize the findings of this paper, argue that the findings may not be uncommon, and opine that this paper presents an approach for ranking emerging markets in terms of their "market integrity."

\section{The Bolsa Mexicana de Valores}

\section{A. Brief History}

Brokerage activities began in Mexico around 1850, when European and American businessmen traded mostly mining shares openly on the streets of Mexico City. On October 31, 1894, the Bolsa Nacional de Mexico (The National Exchange of Mexico) was born. A year later it merged with another group of organized investors. Together these two groups of investors created the Bolsa de Mexico (The Mexican Exchange). It was under this title that trading on the floor began on October 21, 1895. Between that first market and the present-day Bolsa Mexicana de Valores (BMV), a succession of institutions provided facilities for the continuous evolution of trading, which was interrupted only for brief periods, such as the monetary turbulence resulting from changing regimes during the Revolution, and financial difficulties around the world after the First World War. Today the BMV, Mexico's only stock exchange, is a private limited liability institution owned by a few Mexican brokerage houses, each of whom own a single share.

Till 1976, the regulatory framework was defined by the Credit Organizations Law (Ley de Organizaciones de Crédito) of 1932 and the Exchange Regulation Law (Ley Reglamentaria 
de Bolsas) of 1933. In 1975, a new law called the Securities Market Act (Ley del Mercado de Valores ) was formulated, and it is this law that governs the BMV today. ${ }^{6}$

\section{B. Enforcement of Insider Trading Laws}

The Mexican laws on insider trading are similar to those in the United States. Article 16 Bis 8 Ley Mercado de Valores (LMV) states: "Inside information consists of the acts of a corporation, accountants, or administrators of a said corporation, which is not divulged to the public investor, but which can influence the prices and quotations of the stock's price of the said corporation."

The LMV goes on to give examples of such privileged information:

* Changes in the Board of Directors

* Policies for dividends

* Anticipated amortization of obligations

* Strikes and collective conflicts that naturally occur

* Defaults

and it lists who could have such privileged information (Art 16 Bis 1, LMV):

* The administrators, directors, managers, secretaries of the said corporation

* A stockholder with $10 \%$ or more of outstanding equity

* The lenders of independent services to the corporation, the assessors and the businesses of publicity

* Stockholders of $10 \%$ or more of equity of a stock brokerage and the Bolsa specialists of the corporation

* The administrators of the BMV. ${ }^{7}$

The National Banking and Securities Commission regulates the exchange. It is responsible

The information in this sub-section comes mostly from BMV's home page on the Internet.

The information in this sub-section comes from translations from the Spanish made by one of the authors. 
for the enforcement of the insider trading laws.

\section{Types of Shares Traded}

Mexican companies issue many different types of equity, called series. For the purpose of this study, two types of shares interest us: the A-shares and the B-shares. A-shares may legally be held only by Mexican nationals, and account for at least 51 percent of voting rights. B-shares are open to foreigners, and are limited to 49 percent of the ownership. Other than segmentation by ownership, these two series are similar; in particular, owners have equal rights to cash flows and voting privileges. The A-shares and the B-shares, along with the L-shares (which have limited or no voting rights, and are mostly used for ADRs), are the most popular types of outstanding shares.

Another feature that appears as an important criteria in our data screening process is the concentration of trading in the BMV. In a typical day, most listed shares do not trade. A few shares trade a lot. ${ }^{8}$

\section{The Data}

All the daily trading data used for this study were hand-collected from Bloomberg terminals. Corporate news announcements were also obtained from Bloomberg News. Given the limitations of the data collecting process, we chose to limit the period under study from July 1994 through June 1996.

The data were screened using the following process. The number of different types of shares that were trading in the BMV in our period of study was 529. The first screen that we applied was to select firms that had both A-shares as well as B-shares. Only 136 survived this screen (68 A-shares with a matching 68 B-shares). The second screen we applied was to

\footnotetext{
The information in these two paragraphs comes mostly from D omowitz, Glen and M adhavan (1997, 1998). Their first paper documents the effects of share ownership restrictions in Mexico on share prices; their second paper analyzes the costs and benefits of cross-listing a Mexican share by a US ADR.
} 
eliminate all firms that had missing stock price data near the announcement window. Only 98 survived this screen (49 A-shares with a matching 49 B-shares). The third filter we applied was to eliminate all stocks that had no "event-worthy news" in Bloomberg. ${ }^{9}$ Only 38 survived this screen (19 A-shares with a matching 19 B-shares). Fortunately for us, of the 38 shares that survived, 26 shares had two distinct news events that were at least three months apart. This allowed us to increase our sample size to 64 (32 A-shares with a matching 32 B-shares).

Our final data, hence, covers 32 firm-specific news announcements. As we mentioned before, these are all the event-worthy firm-specific Mexican news announcements, for which we have stock price data, that Bloomberg reported in July 1994 through June 1996. We list them in Table I. We also verified them by cross-checking with the local Mexican press. It seems from Table I that the most frequent corporate news from Mexico in 1994-1996, as reported in Bloomberg, related to company restructurings followed by earnings announcements. A casual observation of the daily wire reports in Bloomberg News suggests that this is not very different from U.S. company news in that same period.

The day of the company news announcement has also been listed in Table I, and it is taken to be the day on which the news was first reported in Bloomberg. Since it is difficult for us to pinpoint the exact time the news was made public, for the purpose of this study we define the "event window" to be from a day before to two days afterwards.

We define an "event period" to be from 80 days before the public news announcement to 10 days after (or less, if data at the tails is missing) . We obtained for each of these "event periods", for both A- shares and its matching B-shares, the daily closing bid, ask and transaction prices, and the daily volumes of trade. Data were missing for a few observations. We also collected the daily closing price of the IPC (the popular Mexican stock index) for the period July

"Event-worthy news" includes, but is not restricted to, dividend announcements, earnings announcements, restructuring announcements (changes in capital structure, mergers/takeovers, acquisitions/spinoffs/selloffs), privatization announcements, and board change announcements. 
1994 through June 1996.

\section{The Impact of Corporate News Announcements}

\section{A. Are Returns Abnormal during Corporate News Announcements?}

We test each firm in our sample for abnormal returns for every day in the event period, using the methodology proposed by Brown and Warner (1985). The "normal" period is defined as 80 days before the announcement day to 10 days before the announcement day. We use a market model to define excess returns for each firm for each day. A t-Statistic for each firm for each day is calculated. Our null hypothesis is that excess returns for each day are equal to zero. We use a t-distribution to decide on the rejection of the null -- a two-tailed $t$ test at a $5 \%$ significance level -- on each day.

Figure 1 presents a graph of the percentage of firms that had a rejection of the null hypothesis on each day in the event period, the days ranging from -80 to +10 . The shaded area in the figure highlights the event window (defined as one day before the announcement day to two days after the announcement day, i.e., -1 to +2 ). If the corporate announcement has an effect on stock prices, then we would expect to see more rejections in the shaded area. We do not, either for the A-shares or the B-shares. The proportion of rejections in the event window is not different from that for the rest of the days in the event period. This suggests that corporate announcements in our sample have no impact on returns..$^{10}$

The results presented here relates to individual firms. We are not able to pool abnormal returns and conduct a single test for the totality of our sample. The reason is that the firms in our sample have announcements about events that are different in nature. Some of the announcements will be taken as good news, others will be taken as bad news. Also, some announcements will not be considered news at all. Classifying the announcements ex-ante may not be done. Classifying 
the announcement ex-post, based on the realized excess returns in the event window, would introduce a severe selection bias. For example, classifying positive realizations of excess returns as "good news" will make their excess returns positive by construction, even if the true data generating process has expected excess returns of zero.

The analysis in the next section gets around this problem. Instead of using returns, we use the volatility of returns.

\section{B. Is Volatility Unusual during Corporate News Announcements?}

A large literature relates stock price volatility with the flow of information in financial markets. This section examines if there is any evidence of unusual volatility in the event window.

We take the absolute value of excess returns and pool these over all firms. Absolute values allow us to pool firms that have announcements that are different in nature. Our null hypothesis is that absolute returns during the event window are not higher than those in the "normal" period. The testing methodology used in the previous section is no longer appropriate, since it is based on the fact that sample returns follow a t-distribution (or at least asymptotically). This assumption cannot be made for absolute returns. We therefore use a non-parametric test on mean ranked excess absolute returns as proposed in Corrado (1989). This test does not make any distributional assumptions. It uses the rank of the observations instead of their values. Corrado (1989) shows that this test statistic is well-specified and is asymptotically normally distributed (tdistributed for a finite sample under the null of no abnormal absolute returns). We also try different methods in calculating excess returns: demeaned returns, raw returns minus market returns, and residual returns from the market model.

Table II provides statistics using the Corrado (1989) test for both the A-shares as well as the B-shares. Using a one-tailed test at a 5\% significance level, the table shows that we cannot reject the hypothesis of no abnormal absolute returns in the event window for A-shares (held by citizens only), however we define excess returns. On the other hand, the results concerning B- 
shares (that can be held by foreigners as well) are mixed, allowing the possibility of abnormal volatility in the event window for this type of share.

Figure 2, which is in the spirit of figure 1 of the previous section, presents the results of Table II pictorially. It plots the above rank statistic for each day in the event period, the days ranging from -80 to +10 . The shaded area in the figure highlights the event window (defined as one day before the announcement day to two days after the announcement day, i.e., -1 to +2 ). If the corporate announcement has an effect on stock volatility, then we would expect to see higher values of the rank statistic in the shaded area. We do not see it for the A-shares, but we do see it for the B-shares. This observation is robust to varying the number of days in the event window and using alternative methods to calculate excess returns.

\section{Is Volume Unusual during Corporate News Announcements?}

In the market microstructure literature, high volumes are associated with information arrivals (see Kyle (1985), for example). This section examines if there is any evidence of unusual volume in the event window.

We proceed in two steps. First, an individual share's daily volume in a particular day is divided by the average daily volume for that share in the event period. This gives us a normalized measure that is independent of firm size. Second, the normalized volume for each share is averaged across all shares for each day. Figure 3 plots this daily volume figure in the event period, from day -80 to +10 . As can be seen, there is no unusual volume in the event window for either the A-shares or the B-shares. We notice a large spike after the event window for the B-shares. This abnormal volume is driven by an outlier and took place four days after the announcement day. ${ }^{11}$ 


\section{Are Bid-Ask Spreads Unusual during Corporate News Announcements?}

In the market microstructure literature, unusual bid-ask spreads are related to inventory control problems associated with unusual volatility (see Stoll (1978), and Ho and Stoll (1981, 1983)) or a period of severe asymmetric information (see Glosten and Milgrom (1985) and Kyle (1985)). This section examines if there is any evidence of unusual bid-ask spreads in the event window.

We proceed in two steps. First, an individual share's bid-ask spread in a particular day is calculated as its closing ask less its closing bid divided by the mid-point of the ask and the bid. Second, the bid-ask spreads for each share is averaged across all shares for each day. Figure 4 plots this daily bid-ask spread in the event period, from day -80 to +10 . As can be seen, there is no unusual bid-ask spread in the event window for either the A-shares or the B-shares.

Two observations are warranted. First, notice that the bid-ask spreads are declining as we approach the announcement date. This is consistent with a conclusion we draw in the next section: pre-announcement information leakage exists. Second, the average bid-ask spread is around 5\% in the event period, and this is much higher than the 1996 NYSE estimated average spread of about $0.5 \% .^{12}$ This is consistent with another conclusion we draw in the next section: though there is a lead-lag relationship between prices of A-shares and B-shares, significant transaction costs of trading preclude trading strategies from exploiting this fact.

To summarize this section, the conclusion from the analysis thus far is that the behavior of returns, volatility, volume of trade, and bid-ask spreads points to the fact that, in the period July 1994 through June 1996, Mexican corporate news announcements did not have any noticeable impact on trading on the announcement day. In the next section, we explore why. 


\section{Is it Insider Trading?}

As we discussed before, we might find stock prices to be insensitive to corporate news announcements if our sample size is small; or if markets are inefficient; or if markets are efficient but the corporate news announcements are not value-relevant; or if markets are efficient and corporate news announcements are value-relevant, but they have been fully anticipated; or if markets are efficient and corporate news announcements are value-relevant, but unrestricted insider trading has caused prices to fully incorporate the information.

If any of the first three hypotheses are correct, we should not observe pre-announcement price behavior that suggests an information leakage. On the other hand, if any of the last two hypotheses are correct, we should observe pre-announcement price behavior that suggests a hundred percent information leakage. Let us explore how this might happen in both these last two cases.

Suppose Mexican corporate news announcements are badly kept secrets. Information leaks out into the public domain regularly. Market participants, consequently, update their beliefs. They trade accordingly, and the stock price reflects this information leakage. If the news leakage is extreme, the updated belief could contain the information in the announcement. The announcement would be fully anticipated, and it will not affect prices.

On the other hand, suppose insider trading is rampant in Mexico. Insider trading is trading by a person, who by virtue of his position, has information non-insiders do not have. Through trading, their superior information gets incorporated in stock prices. (See models by Glosten and Milgrom (1985) and Kyle (1985) for a formal exposition of this point.) Prices will move to reflect the information that is leaked through insider trades and, in principle, could incorporate nearly all the information before the announcement. In this case, the announcement will have no news content.

Insider trading is illegal in Mexico. However, given the fact there has never been an 
indictment, trial and/or conviction for insider trading there till June 1996, the possibility of insider trades cannot be ruled out.

It is impossible to distinguish between the last two hypotheses in the United States. ${ }^{13}$ However, Mexico offers us a rare opportunity to do so. The existence of two classes of shares (A-shares and B-shares), which segment by ownership, permits us to analyze the preannouncement price behavior of the two types of shares. If the full anticipation hypothesis holds, both types of shares would exhibit the same time-series price behavior before the announcement. If the insider trading hypothesis holds, the time-series price behavior may be different before the announcement.

A few points need to be made here. First, if we do see different pre-announcement price behavior that reveals a significant information spillover from one type of share to another, it is not only evidence against the full anticipation hypothesis, but it is also evidence against the "small sample," the "market inefficiency" and the "value-irrelevant corporate announcement" hypothesis. Second, if we do document such an information spillover, information should be flowing from the type of share where there is more insider trading to the type of share where there is less insider trading. Since we do not know a priori in which type of share, A-share or B-share, we have more insiders, we cannot a priori hypothesize the direction of information flow. Third, if we do document such an information spillover, considering that citizens may hold both type of shares and foreigners have ways to get around the legal restrictions ${ }^{14}$, we need to explain why this leadlag relationship is not arbitraged away.

We now present three sets of tests that grapple with these issues.

Meulbroek (1992) is a notable exception. Her study was possible because she had access to illegal insider trading data from the SEC. In a few of the 200 plus emerging stock markets of the world, which is the focus of our study, even market regulators do not have this data.

Foreigners can hold A-shares by the way of trusts. 


\section{A. Lead-lag Relationship between A-shares and B-shares}

Lead-lag relationships are best established using the econometric concept of Granger Causality. A variable $\mathrm{x}$ is said to Granger cause another variable $\mathrm{y}$ if lags of $\mathrm{x}$ have an explanatory power in a regression of $y$ on lags of $x$. If variable $x$ Granger causes variable $y$, but variable $y$ does not Granger cause variable $\mathrm{x}$, then we can conclude that $\mathrm{x}$ is the cause and $\mathrm{y}$ is the effect. The Granger Causality test is an F-test of the joint significance of all lags of an explanatory variable. The null hypothesis is that of no joint significance.

In our case, we want to study the flow of information between the two classes of shares. The incorporation of information into prices is best proxied by volatility. Therefore, we need to establish the direction of volatility transmission between the two classes of shares.

Following Comte and Lieberman (1996), we use the notion of Granger Causality in Variance. Granger Causality is best tested in the framework of a Vector Auto Regressions (VAR). We set up a simple two variables VAR with the variance of returns of A-shares and Bshares as the endogenous variables. We use a standard Likelihood Ratio test to choose the number of lags in our two equations VAR (See Enders (1996)). The procedure is that of sequential hypothesis testing. Essentially, we start with a one lag model and then test if we can reject that adding another lag does not improve the explanatory power of the model. The procedure is repeated until the hypothesis cannot be rejected. At this point, we have enough lags in our model. Panel A of table III presents results of the Likelihood Ratio test on increasing the number of lags. The model chosen by the test is one with 4 lags.

Panel B of table III reports results of the Granger Causality test for our 4 lags model. For robustness, we also conduct the test with a 3 lags model and a 5 lags model. They all give the same unambiguous result. Volatility of returns of A-shares Granger cause volatility of returns of B-shares; the reverse is not true. This implies that information spills from A-shares to B-shares, and not vice-versa, which hints that insider trading may be the cause of Mexican corporate 
announcements being non-events. ${ }^{15}$

B. Why is the lead-lag relationship between A-shares and B-shares not arbitraged away?

We have just documented that A-shares lead B-shares in terms of information revelation. Is it possible for market participants to use this fact to devise profitable trading strategies? The idea is that market participants would be able to observe the movements in A-shares and infer some of the information that insiders have. Then, knowing this information, they would trade in B-shares to exploit the fact that B-shares have not reflected the information as yet. If market participants can apply these strategies profitably, we should not observe any lead-lag relationship between A-shares and B-shares.

Define an $(i, t)$ technical trading strategy in the following way: open a position by buying (selling) the B-shares when the cumulated percentage difference in returns between A-shares and B-shares, cumulated over $t$ days, is greater than (is less than) a trigger $+\mathrm{i}(-\mathrm{i})$. Close the position when the reverse trigger occurs or when the end of the event window is reached, whichever comes first. For example, the (4,3) strategy would involve buying B-shares when the 3-day cumulative difference in returns between A-shares and B-shares is greater than +4 percent, and to close the position when the 3-day cumulative difference in returns between A-shares and Bshares is less than -4 percent or the last date of the event window is reached, whichever comes first.

The (i, t) technical trading strategy captures the essence of our intuition. If a divergence between the returns of A-shares and B-shares is due to insider information that is incorporated in A-shares but is not incorporated in B-shares, it is expected that B-shares would soon catch up to A-shares as this information spills over. Given the amount of noise in share prices, it would be profitable to take a position in B-shares when the divergence is more than a threshold value

In a different context, Frankel and Schmukler (1996) documented that during the "peso crisis" of December 1994, the Net Asset Values of mutual funds held mostly by Mexicans Granger caused Net Asset Values of mutual funds held mostly by foreigners. They concluded that the first to flee were not fickle foreign investors but well-informed Mexican investors. 
(the i). Not knowing a priori the exact time it takes for the information to spill over, it would be wise to check a range of times (the t).

We first ignore the transaction costs of trading; we assume that all buys and sells occur at the mid-point of the bid and ask prices. Figure 5 presents the raw returns that can be made with various $(\mathrm{i}, \mathrm{t})$ technical trading rules. Varying $\mathrm{i}$ from 1 per cent to 30 percent, and $\mathrm{t}$ from 1 day to 4 days, we notice that substantial 91 day returns can be made for many of the $(i, t)$ technical trading strategies. The highest is the $10.1 \%$ obtained from the $(13,2)$ trading rule. This supports our earlier findings that A-shares contain information that are not yet revealed by Bshares. ${ }^{16}$

Given this finding, the question is why are market participants not using these strategies and arbitraging away the lead-lag relationship between A-shares and B-shares. The answer is transaction costs.

If we do not ignore transaction costs, and assume that all buys are executed at the ask and all sells are executed at the bid, there are no profits to be made. This is shown in figure 6 . As can be seen, almost all the strategies that were previously yielding positive gross returns now yield net negative returns. For low i's, the loss is substantial because these rules imply a high frequency of trades, and therefore high transaction costs. For the other i's, the loss is less pronounced. Moreover, in some rare cases, there is even a net positive return.

However, the net positive returns that we can obtain from some of the technical trading rules does not imply riskless arbitrage opportunities. First and foremost, the highest return from the best strategy is less than the risk-free rate in Mexico during that period. Specifically, the lowest level attained by the 3 months Mexican T-bill (Cetes) is 5\% for 91 days in our sample period, whereas the return on the best trading rule yields after transaction costs $2.8 \%$ for 91 days. 
Second, notice that we choose our best trading rule ex-post. In the real world, market participants would not know this ex-ante. Third, observe that we assume that market participants follow these $(\mathrm{i}, \mathrm{t})$ trading rules because they know that the firm is going to make an announcement. In the real world, market participants do not know this for sure.

These reasons allow us to conclude that even if market participants are aware that Ashares lead B-shares, they cannot use this information to trade profitably and thus destroy the lead-lag relationship.

We conclude with one last test.

C. Who is surprised more by the announcement - the holders of the A-shares or the holders of the B-shares?

For each firm, for each type of share, for each day in an event period $(-80$ to +10$)$, we calculated the absolute value of residuals from a market model of returns. We then averaged the absolute value of residuals over all share types for each day in the event period. ${ }^{17}$ We then cumulated through event time, -80 to +10 . Finally, since cumulative absolute values will have an upward drift by construction, the series was detrended by regressing it on a time trend. Figure 7 is a plot of the detrended cumulative absolute abnormal returns around the corporate announcement. ${ }^{18}$ A sharp blip in the event window would suggest abnormal returns in that period, the "surprise" element in the corporate news announcement.

In Figure 7, we notice that though both types of shares show little reaction during the announcement, the reaction of the A-shares is even less than the reaction of the B-shares. So holders of the A-shares are less surprised by the announcement than holders of the B-shares. This is consistent with our previous findings of the lead-lag relationship between A-shares and B-

We used absolute values of abnormal returns here rather than follow the conventional practice of using raw abnormal returns, because we were pooling different types of events (some of which were "good news" events and some of which were "bad news" events).

18 We re-plotted the graph using demeaned raw returns, and raw returns minus market returns. Our conclusions do not change. 
shares, seen in Table III and Figures 5 and 6. It is also consistent with the observations we made from Table II, and from Figures 1 through 4: though news announcements seem to have no differential impact on A-shares and B-shares with respect to returns, volume of trade, or bid-ask spreads, there is a differential impact with respect to volatility.

A possible critique of the above differential response test is that A-shares are held by Mexican institutional investors who trade much less than the foreign holders of the B-shares. If that is the case, the above differential tests are revealing the bias caused by the staleness of prices in the A-shares.

There is some truth to the above criticism. We found that in our event period the volume of trade of A-shares was about $74 \%$ of the volume of trade of B-shares. The average A-share had 37 days with a price change and 50 days with a positive volume, whereas the average B-share had 49 days with a price change and 60 days with a positive volume. So B-shares are more liquid than A-shares.

The previous lead-lag tests, however, are immune to the above criticism. They are based on the premise that if the holders of the A-shares really know more, and are trading on their superior information, volatility of the returns of A-shares would lead the volatility of the returns of B-shares. We detected this. We would not have been able to detect this if the staleness of prices of A-shares was significant.

\section{Conclusions}

Using a data set of corporate news announcements in Mexico from July 1994 through June 1996, this paper documents that nothing much happens to the firm's stock price on the day of the event. Returns, volatility of returns, volume of trade, and bid-ask spreads are not atypical in the event window. Further classification into A-shares (which only citizens may hold) and Bshares (which foreigners can hold) reveals that this lack of reaction is mostly concentrated in the 
A-shares, suggesting that foreigners are more surprised than the locals. This, and the result that the return volatility of A-shares leads return volatility of B-shares (but not strongly enough for there to exist trading rules to arbitrage it away), insinuate that it is insider trading that is responsible for a Mexican corporate news announcement to be a non-event.

How common is this occurrence? Have we discovered a rare phenomenon that is unique to a particular stock market at a particular point in time in its history? Though answers to these questions are beyond the scope of this paper, it is our contention that this phenomenon is not restricted to Mexico in the period July 1994 through June 1996. An examination of the data in de Caires (1987) shows that in only 26 stock markets of the world, insiders are required to either abstain from trading or disclose their information before doing so. While this study is dated, we do not think that insider trading regulations have expanded so much as to cover all the 200 plus stock markets that exist today. It is even more unrealistic to hope that they are enforced in all of them.

If insider trading is the rule rather than the exception in the majority of existing stock markets, many interesting research questions open up. We identify two of them.

The first research area is a quest to develop a metric to rank stock markets in terms of their "market integrity." The importance of this metric for foreign institutional investors cannot be overemphasized. ${ }^{19}$ Given the lack of high-frequency transaction data that is available for developed stock markets, which ironically have the least need to be ranked in terms of "market integrity," researchers have to develop methodologies that can be used with the limited data available in emerging stock markets. Though we have not developed a measure for market integrity in this paper, we have indicated an approach. This approach requires one to check the impact of firm-specific announcements on share prices and, if one finds a negligible response, to

Foreign institutional investors are beginning to have a significant impact on emerging markets. In Mexico, for example, Domowitz, Glen and Madhavan (1997) report that foreigners (mostly U.S. nationals) account for over 27 per cent of holdings and up to 75 per cent of trading in their 1990-1993 sample period. 
further check for pre-announcement lead-lag relationships amongst various types of shares. ${ }^{20}$

The second research question, which was first raised by Hubermam and Schwert (1985), is: if prices do not react to news announcements, how does an econometrician date an event in an "event study"? 


\section{REFERENCES}

Alexander, G., C. Eun, and S. Janakiraman, 1988, International Listings and Stock Returns: Some Empirical Evidence, Journal of Financial and Quantitative Analysis 23, 135-151.

Bailey, W. and J. Jagtiani, 1994, Foreign Ownership Restrictions and Stock Prices in the Thai Capital Market, Journal of Financial Economics 36, 57-87.

Ball, R. and P. Brown, 1968, An Empirical Evaluation of Accounting Income Numbers, Journal of Accounting Research 6, 159-178.

Bodie, Z., A. Kane and A. Marcus, 1996, Investments (Third Edition, Irwin, Chicago, IL.)

Brown, K., W. Harlow and S. Tinic, 1988, Risk Aversion, Uncertain Information, and Market Efficiency, Journal of Financial Economics 22, 355-385.

Brown, S. and J. Warner, 1985, Using Daily Stock Returns: The Case of Event Studies, Journal of Financial Economics 14, 3-31.

Campbell, J., A. Lo and C. MacKinlay, 1997, The Econometrics of Financial Markets (Princeton University Press, Princeton, N.J.)

Chan K.C., W. Fong and R. Stulz, 1995, Information, Trading, and Stock Returns: Lessons from DuallyListed Securities, Journal of Banking and Finance 20, 1161-1187.

Comte, F. and O. Lieberman, 1996, On Variance, Non Causality and Cointegration, working paper, Israel Institute of Technology.

Corrado, C., 1989, A Non Parametric Test for Abnormal Security-Price Performance in Event Studies, Journal of Financial Economics 23, 385-395.

de Caires, B. (ed,), The GT Guide to World Equity Markets 1987, Euromoney Publications PLC, London.

Domowitz, I., J. Glen and A. Madhavan, 1997, Market Segmentation and Stock Prices: Evidence from an Emerging Market, Journal of Finance 52, 1059-1085. 
Domowitz, I., J. Glen and A. Madhavan, 1998, International Cross-Listing and Order Flow Migration: Evidence from an Emerging Market, forthcoming, Journal of Finance.

Enders, W., 1996, RATS Handbook for Econometric Time Series (John Wiley and Sons, New York)

Fama, E., L. Fisher, M. Jensen, and R. Roll, 1969, The Adjustment of Stock Prices to New Information, International Economic Review 10, 1-21.

Fama, E., 1997, Market Efficiency, Long-Term Returns, and Behavioral Finance, working paper, University of Chicago.

Foerster, S. and G. Karolyi, 1993, International Listing of Stocks: The Case of Canada and the U.S., Journal of International Business Studies 24, 763-784.

Frankel, J. and S. Schmukler, 1996, Country Fund Discounts and the Mexican Crisis of December 1994: Did Local Residents Turn Pessimistic Before International Investors? Open Economies Review 7, 511-534.

Forster, M. and T. George, 1996, Pricing Errors at the NYSE Open and Close: Evidence from Internationally Cross-Listed Stocks, Journal of Financial Intermediation 5, 95-126.

Glosten, L. and P. Milgrom,1985, Bid, Ask and Transaction Prices in a Specialist Model with Heterogeneously Informed Traders, Journal of Financial Economics 14, 71-100.

Ho, T. and H. Stoll, 1981, Optimal Dealer Pricing under Transactions and Return Uncertainty, Journal of Financial Economics 9, 47-73.

Ho, T., and H. Stoll, 1983, The Dynamics of Dealer Markets under Competition, Journal of Finance 38, $1053-1074$.

Huberman, G. and G.W. Schwert, 1985, Information Aggregation, Inflation, and the Pricing of Indexed Bonds, Journal of Political Economy 93, 92-114..

Jayaraman N., K. Shastri and K. Tandon, 1993, The Impact of International Cross Listings on Risk and Return: The Evidence from American Depository Receipts, Journal of Banking and Finance 17, 91-103. 
Jorion, P. and E. Schwartz, 1986, Integration versus Segmentation in the Canadian Stock Market, Journal of Finance 41, 603-616.

Kleidon, A. and I. Warner, 1996, U.K. and U.S. Trading of British Cross-Listed Stocks: An Intraday Analysis of Market Integration, The Review of Financial Studies 9, 619-664.

Kyle, A., 1985, Continuous Auctions and Insider Trading, Econometrica 53, 1315-1335.

McWilliams, A. and Siegel, D., 1997, Event Studies in Management Research: Theoretical and Empirical Issues, Academy of Management Journal 40, 626-657.

Meulbroek, L., 1992, An Empirical Analysis of Illegal Insider Trading, Journal of Finance 47, 16611699.

Mitchell, M. and J. Netter, 1994, The Role of Financial Economics in Securities Fraud Cases: Applications at the Securities and Exchange Commission, The Business Lawyer 49, 545-590.

New York Stock Exchange Fact Book, 1996.

Salinger, M., 1992, Standard Errors in Event Studies, Journal of Financial and Quantitative Analysis 27, 39-53.

Stoll, H., 1978, The Supply of Dealer Services in Securities Markets, Journal of Finance, 33, 1133-1151.

Stulz, R. and W. Wasserfallen, 1996, Foreign Equity Investment Restrictions, Capital Flight, and Shareholder Wealth Maximization: Theory and Evidence, The Review of Financial Studies 8, 1019-1057.

Umlauf, S., 1993, Transaction Taxes and the Behavior of the Swedish Stock Market, Journal of Financial Economics 33, 227-240. 


\section{Table I}

\section{Company News Announcements in Mexico (J uly 1994 through J une 1996)}

Company news announcements in Mexico were obtained from Bloomberg News. The event day is the day in which it was reported. We index this as 0 . The "event period" is -80 to +10 (or less, if data at the tails is not available). The majority (18) of the announcements are restructuring announcements (changes in capital structure, joint ventures, mergers/takeovers, acquisitions/spinoffs/selloffs) followed by earnings announcements (12).

\begin{tabular}{|c|c|c|c|}
\hline Company & Symbol & Event Window & Event and Event Date \\
\hline Argos & ARGOS A/B & $3 / 31 / 95-8 / 4 / 95$ & A bnormal earnings report (J uly 28,1995$)$ \\
\hline Argos & ARGOS A/B & $4 / 8 / 94-8 / 12 / 94$ & First half net drops $43 \%$ to 22.68 pesos (J uly 29,1994 ) \\
\hline Banacci & BANAC A/B & $7 / 29 / 94-12 / 2 / 94$ & Banacci and A egon form insurance company (November 18,1994 ) \\
\hline Banacci & BANAC A/B & $6 / 27 / 94-10 / 31 / 94$ & Banacci signs with $\mathrm{M} \mathrm{Cl}$ (October 17,1994$)$ \\
\hline Cifra & CIFRA A/B & $6 / 23 / 94-10 / 27 / 94$ & Wal-M art, Dillard and Cifra announce joint venture to open stores (October 14,1994$)$ \\
\hline Cifra & CIFRA A/B & $10 / 3 / 94-2 / 6 / 95$ & W al-M art suspends M exican expansion (J anuary 23,1995$)$ \\
\hline Herdez & GHAC/GHBC & $4 / 5 / 95-8 / 9 / 95$ & Hormel explores formation of food venture with Grupo Herdez (J uly 26, 1995) \\
\hline Herdez & GHAC/GHBC & $11 / 2 / 95-3 / 7 / 96$ & Hormel agrees to joint venture with Grupo Herdez (F ebruary 22, 1996) \\
\hline Kimber & $\mathrm{KCM} \mathrm{A/B}$ & $12 / 29 / 94-5 / 4 / 95$ & Kimber de M exico first quarter net $96 \%$ lower than year ago (A pril 20, 1995) \\
\hline Kimber & $\mathrm{KCM} \mathrm{A/B}$ & $11 / 29 / 95-4 / 3 / 96$ & Kimber to swap 73.5 million shares for Crisoba (M arch 20, 1996) \\
\hline Pond & POND A/B & $4 / 11 / 94-8 / 15 / 94$ & Ponderosa first half loss doubles to 155.2 million pesos (A ugust 1,1994 ) \\
\hline Sidek & SIDEK A/B & $10 / 26 / 94-3 / 11 / 95$ & Sidek defaults on debts (F ebruary 15,1995 ) \\
\hline Sidek & SIDEK A/B & $12 / 12 / 95-4 / 16 / 96$ & Sidek presents plan to restructure and cut debt (A pril 2, 1996) \\
\hline Desc & DESC A/B & $4 / 5 / 95-8 / 9 / 95$ & Desc profit soars $600 \%$ (July 27,1995$)$ \\
\hline Desc & DESC A/B & $8 / 30 / 95-1 / 3 / 96$ & Desc announces limited partnership in Invermexico (D ecember 20,1995$)$ \\
\hline GF Norte & GFNORTE A/B & $7 / 7 / 95-11 / 10 / 95$ & Net earnings down 23\% from third quarter of 1994 (October 27, 1995) \\
\hline GFB & GFB A/B & $6 / 8 / 94-10 / 12 / 94$ & GTE-GFB (BANCOMER) merger announcement (September 28, 1994) \\
\hline Gissa & GISSA A/B & $11 / 16 / 94-3 / 22 / 95$ & Grupo Saltillo to buyback class A and B shares of Gissa (M arch 8, 1995) \\
\hline Gissa & GISSA A/B & $10 / 27 / 95-3 / 1 / 96$ & Earnings of fourth quarter of 1995 up $35.4 \%$ (F ebruary 16,1996 ) \\
\hline Cemex & CEMEX A/B & $4 / 12 / 95-8 / 16 / 95$ & $\begin{array}{l}\text { Bank of A merica finally decides to buy } \$ 399 \text { million of commercial paper (A ugust } \\
2,1995 \text { ) }\end{array}$ \\
\hline Cemex & CEMEX A/B & $9 / 18 / 95-1 / 22 / 96$ & Cemex ends tender offer to buy Tolmex (J anuary 1,1996$)$ \\
\hline Ericsson & TIE A/B & $7 / 18 / 94-11 / 21 / 94$ & Ericsson offers to buy back its own shares (November 7, 1994) \\
\hline GBM Atl & GFA A/B & 10/5/94 - 2/8/95 & GBM A tlantico 1994 net drops 55\% (J anuary 25, 1995) \\
\hline
\end{tabular}


GBM At1 GFA A/B

Inbursa INBUR A/B

Inbursa INBUR A/B

Inverlat INLAT A/B

San Cris CRIS A/B

San Cris CRIS A/B

Seguro SEGC A/B

Situr $\quad$ SITUR A/B

Situr SITUR A/B
$5 / 15 / 95-9 / 18 / 95$

$7 / 4 / 94-11 / 7 / 94$

$12 / 7 / 95-4 / 11 / 96$

$8 / 10 / 95-12 / 14 / 95$

$4 / 5 / 94-8 / 9 / 94$

$11 / 29 / 95-4 / 3 / 96$

$7 / 8 / 95-11 / 8 / 95$

$7 / 7 / 95-11 / 10 / 95$

$12 / 12 / 95-4 / 16 / 96$
GBM A tlantico agrees to government aid package (September 5, 1995)

Grupo Inbursa third quarter net doubles to 825 million pesos (October 24, 1994)

Grupo Inbursa buys 40\% stake in M edcom DTH television venture (M arch 28, 1996)

M exico to bail out Inverlat (N ovember 30, 1995)

San Cristobal first half net doubles to 49.2 million pesos (J uly 29, 1994)

Kimber to swap 73.5 million shares of San Cristobal (M arch 20, 1996)

Seguro's N et Income rises $64 \%$ in third quarter (October 25, 1995)

Situr sales down 55\% (October 27,1995)

Situr presents plan to restructure and cut debt (A pril 2, 1996) 


\section{Table II}

\section{Rank Test for Volatility}

We calculated the absolute value of residuals. The null hypothesis is that the absolute value of residuals for the event window $(-1$ to +2$)$ are higher than those in the event period $(-80$ to +10$)$. A one-tailed t-test (see Corrado (1989)) is used.

F or each share i, we sort the 91 days of absolute values of residuals in descending order. D efine $K_{i t}$ as the rank of the absolute value of the residual in date t. The test statistic is: $T=\frac{\mu(K)}{\sigma(K)}$ where the point estimate $\mu(K)$ is $\mu(K)=\frac{1}{N} \sum_{i=1}^{N}\left(\sum_{t=-1}^{2}\left(K_{i t}-45.5\right)\right)$ and the standarad deviation $\sigma(K)$ is calculated using the entire 91-day sample period:

\begin{tabular}{lccc}
$\left.\sigma(K)=\sqrt{\frac{4}{91} \sum_{t=-0}^{+10}\left(\frac{1}{N} \sum_{i=1}^{N}\left(K_{i t}-45.5\right)\right.}\right)$ & \\
\hline & $\mu(\mathrm{K})$ & $\sigma(\mathrm{K})$ & $\mathrm{T}$ \\
\hline Raw, A shares & 4.688 & 7.625 & 0.615 \\
Raw, B shares & 12.156 & 7.485 & 1.624 \\
Index, A shares & 2.375 & 9.428 & 0.252 \\
Index, B shares & 16.000 & 9.426 & $1.698^{*}$ \\
M arket, A shares & 15.141 & 9.576 & 1.581 \\
M arket, B shares & 16.844 & 9.147 & $1.841^{*}$
\end{tabular}

* Statistically significant at the 5 percent level.

"R aw" refers to residuals that were calculated as demeaned returns. "Index" refers to residuals that were calculated as returns less the M exican stock market index. "M arket" refers to residuals that are defined using a market model. 


\section{Table III}

\section{Granger Causality Tests for A and B shares}

This table reports results from a two variables V ector A uto Regression (VAR) system of equations, with the two endogenous variables being

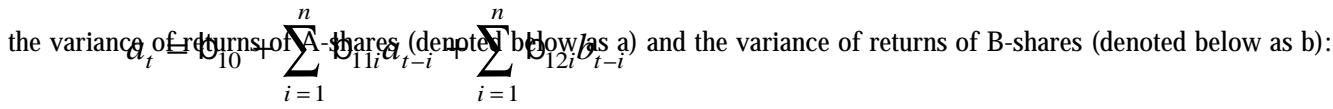

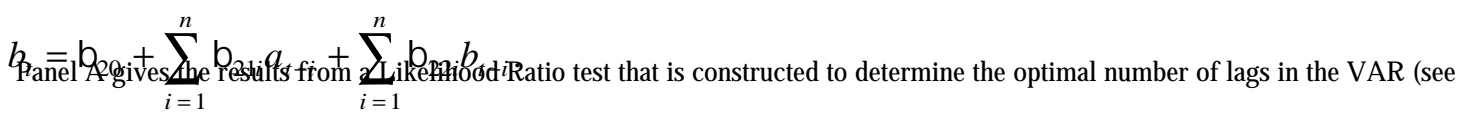
Enders (1996)). " $\log$ Determinant $t$ " is that of a VAR with $t$ number of lags. " $\log$ Determinant $t+1$ " is that of a VAR with $t+1$ number of lags. "Chi-Squared" gives the Chi-Squared statistic for the null hypothesis that an additional lag is not adding explanatory power to the model.

"Significance level" provides the significance level of the Chi-squared statistic.

Panel B reports the results of Granger causality tests for three different models with 4, 3, and 5 lags respectively. "A-shares F-stat" gives the $\mathrm{F}$-statistic for the hypothesis that lags of A-shares do not Granger cause the dependent variable. "B shares F-stat" gives the F-statistic for the hypothesis that lags of B-shares do not Granger cause the dependent variable. The significance level of the corresponding F-statistic is given under "A shares Signif" and "B shares Signif". L ow values of significance level indicate Granger causality.

\begin{tabular}{lcccc}
\hline \multicolumn{4}{c}{ Panel A : Likelihood Ratio Test } \\
\hline & Log Determinant t & Log Determinant t + & Chi-Squared & Significance level \\
\hline 1 lag vs 2 lags & -2.249572 & -2.248937 & 17.869 & 0.00131 \\
2 lags vs 3 lags & -2.247900 & -2.247451 & 12.480 & 0.01411 \\
3 lags vs 4 lags & -2.247883 & -2.247455 & 11.743 & 0.01936 \\
4 lags vs 5 lags & -2.246212 & -2.246101 & 3.0300 & 0.55282 \\
\hline
\end{tabular}

Panel B: F-Stats

\begin{tabular}{|c|c|c|c|c|c|}
\hline D ependent & \# lags & A shares F-stat & A shares Signif & B shares F-stat & B shares Signif \\
\hline A shares & 4 lags & 26.1725 & 0.0000 & 1.5529 & 0.1842 \\
\hline B shares & 4 lags & 102.8212 & 0.0000 & 61.6511 & 0.0000 \\
\hline A shares & 3 lags & 32.4035 & 0.0000 & 2.1975 & 0.0863 \\
\hline B shares & 3 lags & 135.7412 & 0.0000 & 81.3329 & 0.0000 \\
\hline A shares & 5 lags & 20.9449 & 0.0000 & 1.4031 & 0.2199 \\
\hline B shares & 5 lags & 83.4905 & 0.0000 & 50.8930 & 0.0000 \\
\hline
\end{tabular}




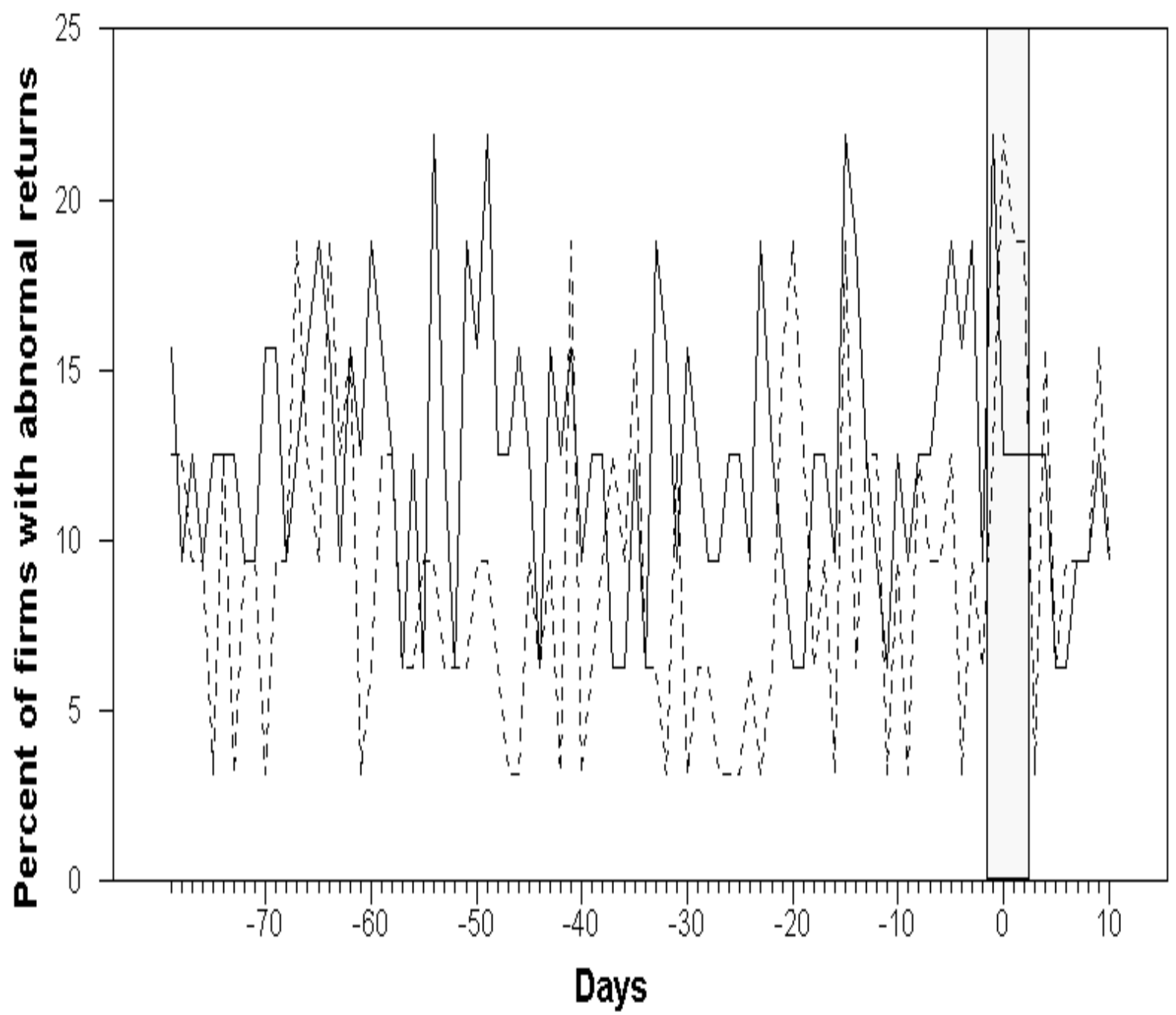

Figure 1. Percentage of firms with abnormal returns. This figure presents a graph of the percentage of firms whose returns were abnormal on a particular day. The $y$-axis gives the percentage of firms that had a rejection of the null hypothesis that returns were not abnormal on day $t$, where t ranges from -80 to +10 . The shaded area in the figure highlights the announcement event window $(-1$ to +2$)$. The solid line represents A shares. The dashed line represents B shares. 


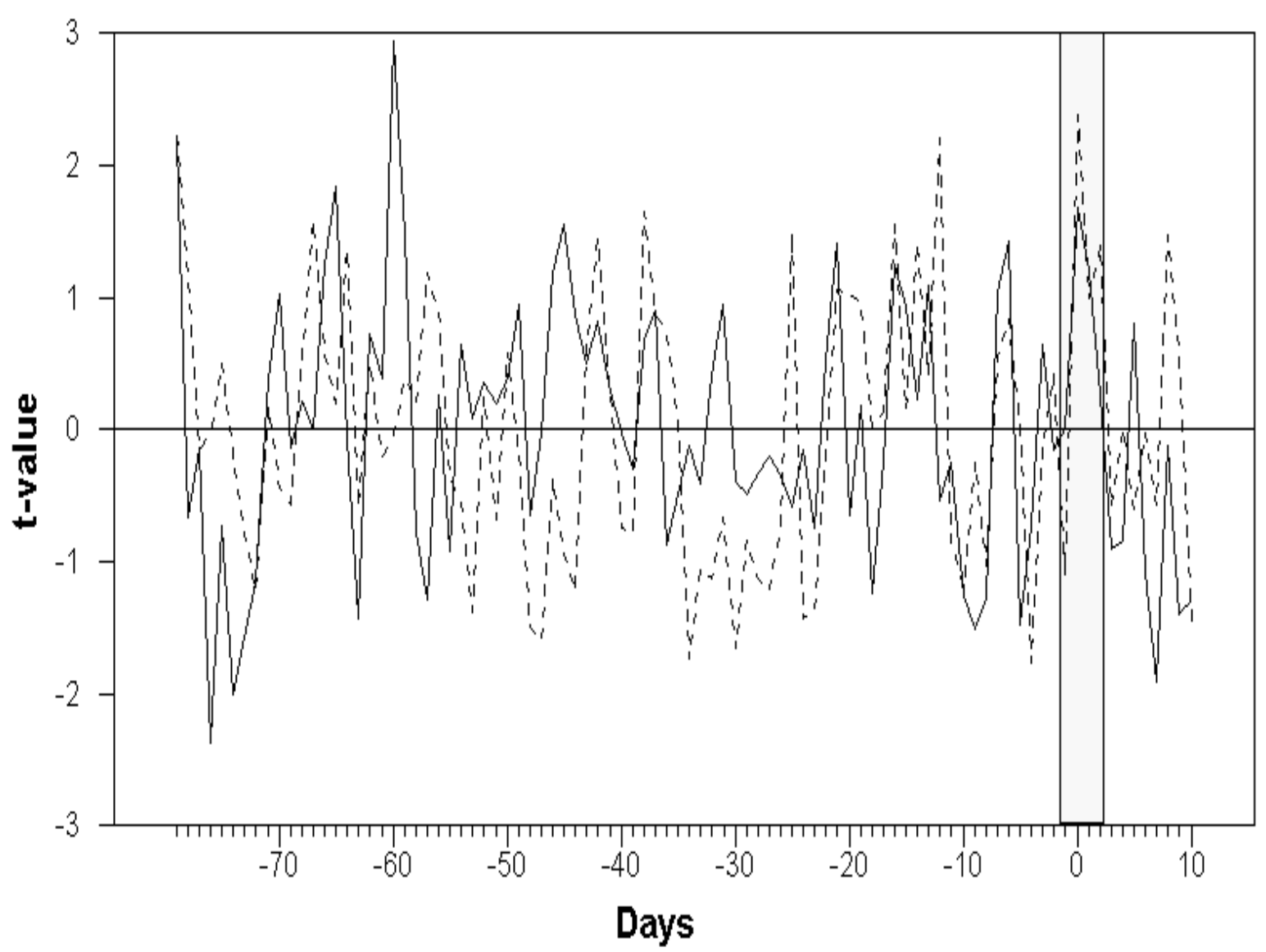

Figure 2. R ank statistics of abnormal volatility. The t-value is the rank statistic obtained following a methodology proposed by Corrado (1989). The y-axis gives the t-value of the Corrado (1989) test, where the null hypothesis is that volatility (measured as absolute residual returns) is not abnormal on day $t$, where $t$ ranges from -80 to +10 . The shaded area in the figure highlights the announcement event window $(-1$ to +2$)$. The solid line represents $A$ shares. The dashed line represents $B$ shares. 


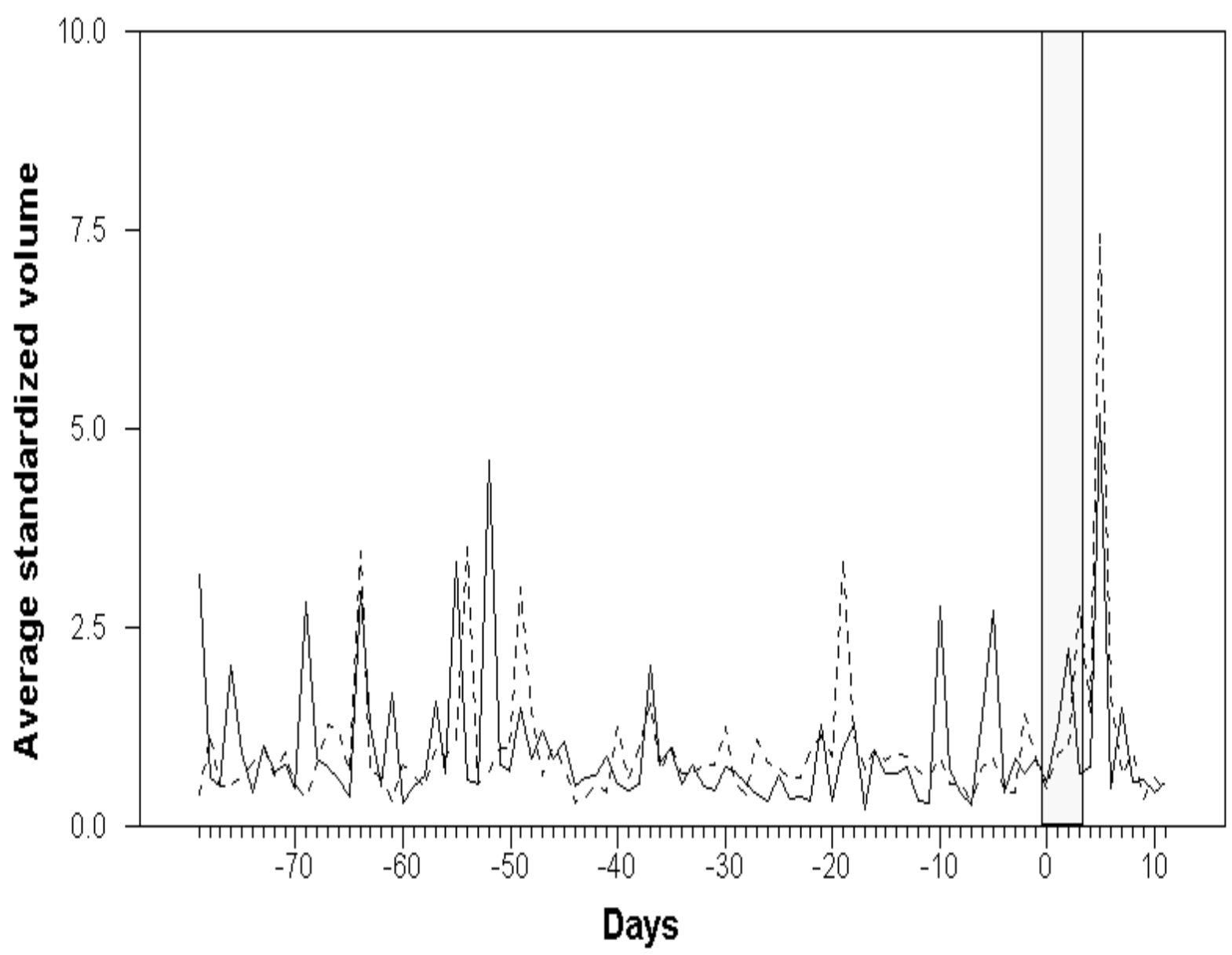

Figure 3. Average standardized volume. A verage standardized volume was calculated in two steps. First, an individual share's daily volume was divided by the average daily volume for that share to give us a measure that is independent of firm size. Second, the normalized volume for each share were averaged over all shares. The y-axis gives this average standardized volume on day $t$, where t ranges from -80 to +10 . The shaded area in the figure highlights the announcement event period $(-1$ to +2$)$. The solid line represents A shares. The dashed line represents B shares. 


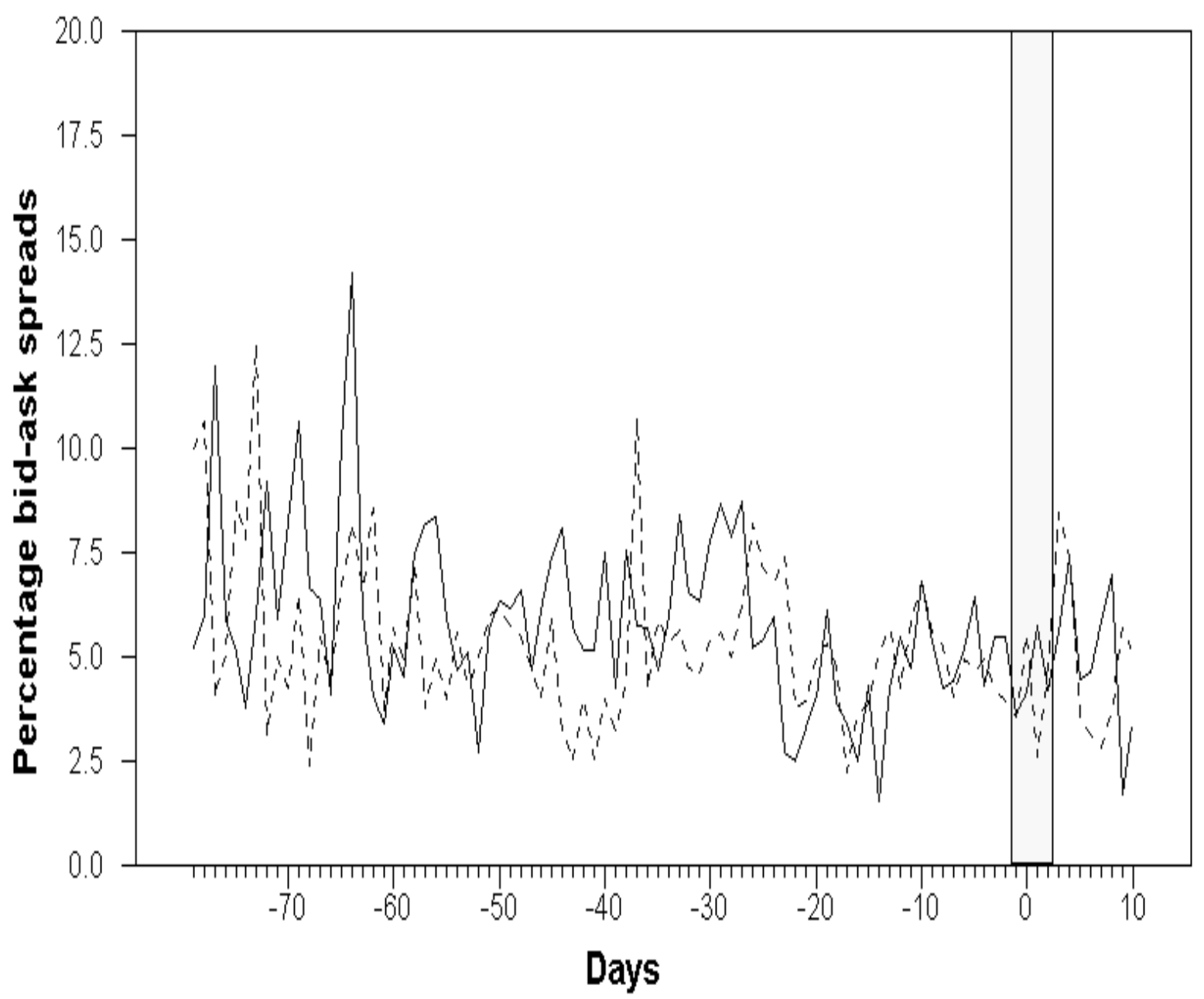

Figure 4. Percentage bid-ask spreads. Percentage bid-ask spread of each stock was calculated as the ask less the bid divided by the midpoint (average of ask and bid). This was then averaged across all stocks. The $y$-axis gives this percentage bid-ask spread on day $t$, where t ranges from -80 to +10 . The shaded area in the figure highlights the announcement event window $(-1$ to +2$)$. The solid line represents A shares. The dashed line represents B shares. 

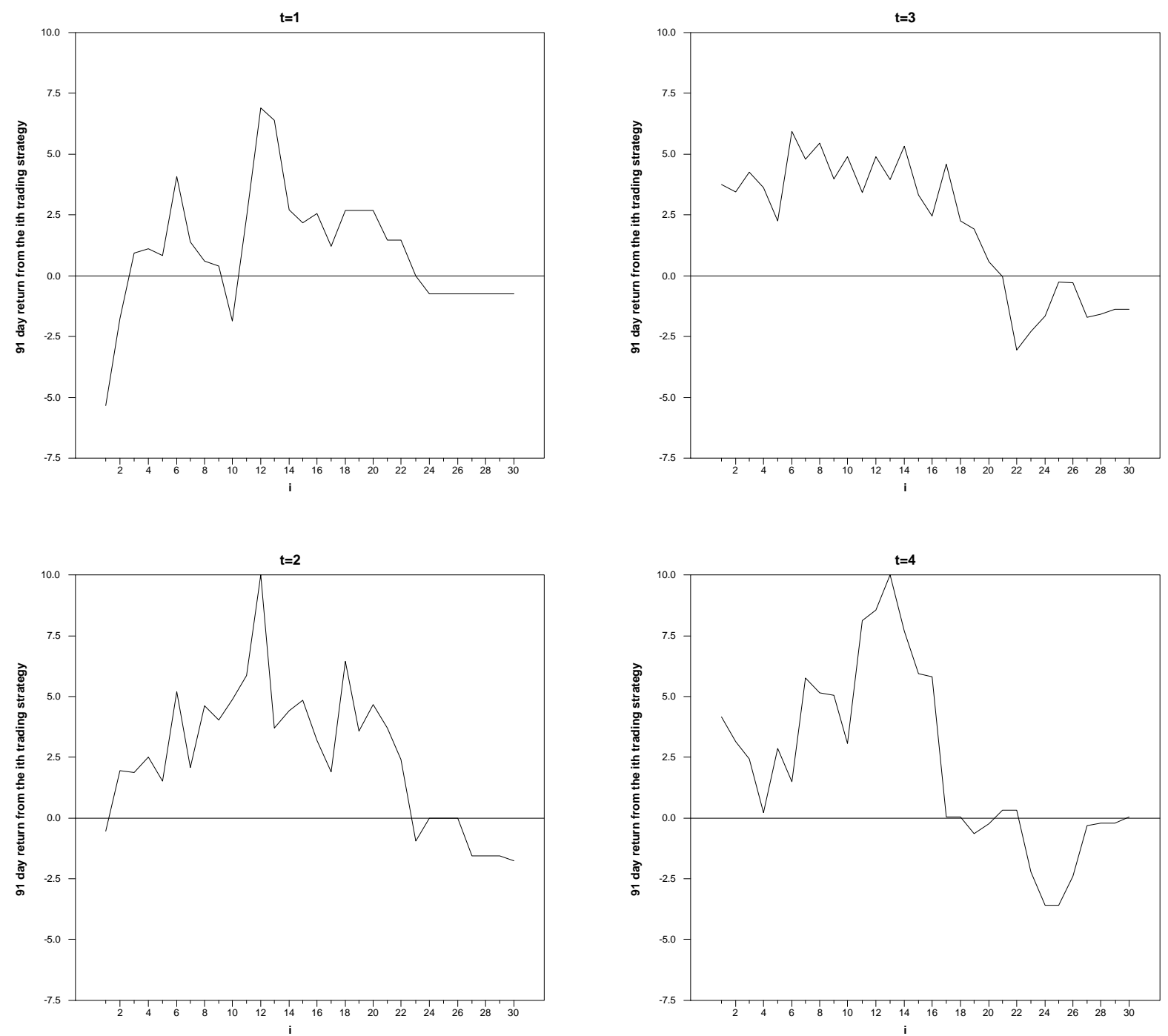

Figure 5. Returns ignoring transaction costs for different trading rules. The graphs plot 91 day returns ignoring transaction costs obtained from the $(i, t)$ technical trading strategy. $A n(i, t)$ technical trading strategy is defined in the following way: open a position by buying (selling) the B-shares when the cumulated percentage difference in returns between $A$-shares and $B$-shares, cumulated over $t$ days, is greater than (is less than) the trigger $+\mathrm{i}(-\mathrm{i})$. Close the position when the reverse trigger occurs or when the end of the event window is reached, whichever occurs first. 
$t=1$

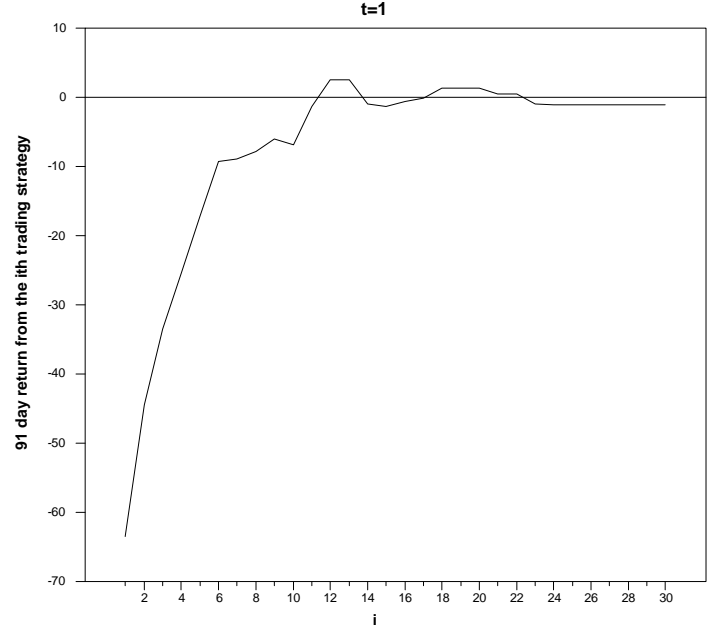

$\mathrm{t}=2$

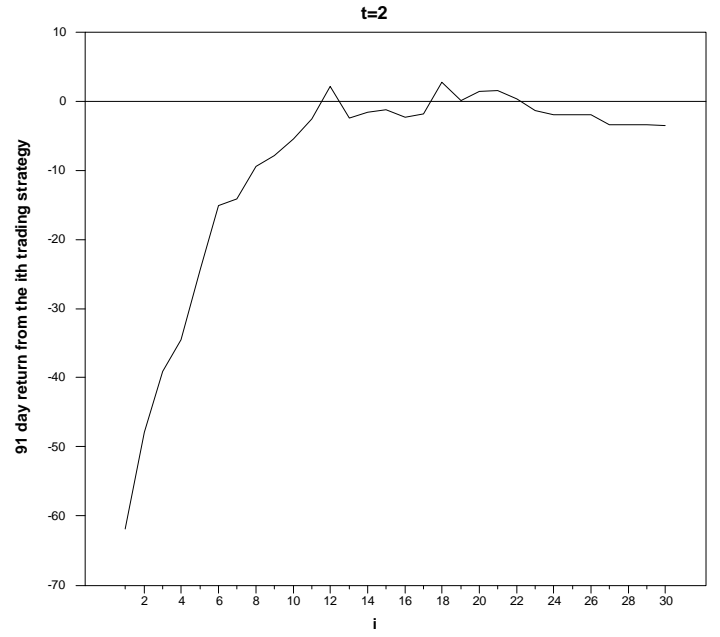

$t=3$

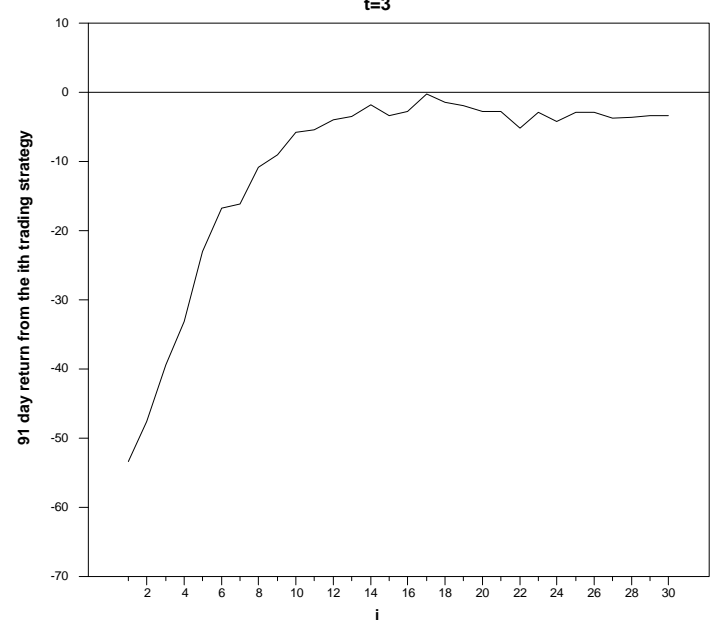

$t=4$

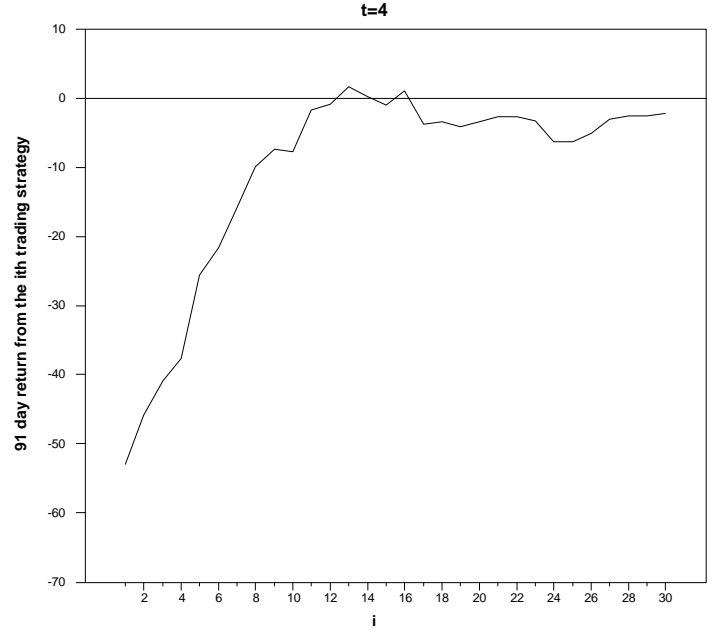

Figure 6. Returns including transaction costs for different trading rules. The graphs plot 91 day returns including transaction costs obtained from the $(i, t)$ technical trading strategy. $A n(i, t)$ technical trading strategy is defined in the following way: open a position by buying (selling) the B-shares when the cumulated percentage difference in returns between $\mathrm{A}$-shares and $\mathrm{B}$-shares, cumulated over $\mathrm{t}$ days, is greater than (is less than) the trigger $+i(-i)$. Close the position when the reverse trigger occurs or when the end of the event window is reached, whichever comes first. 


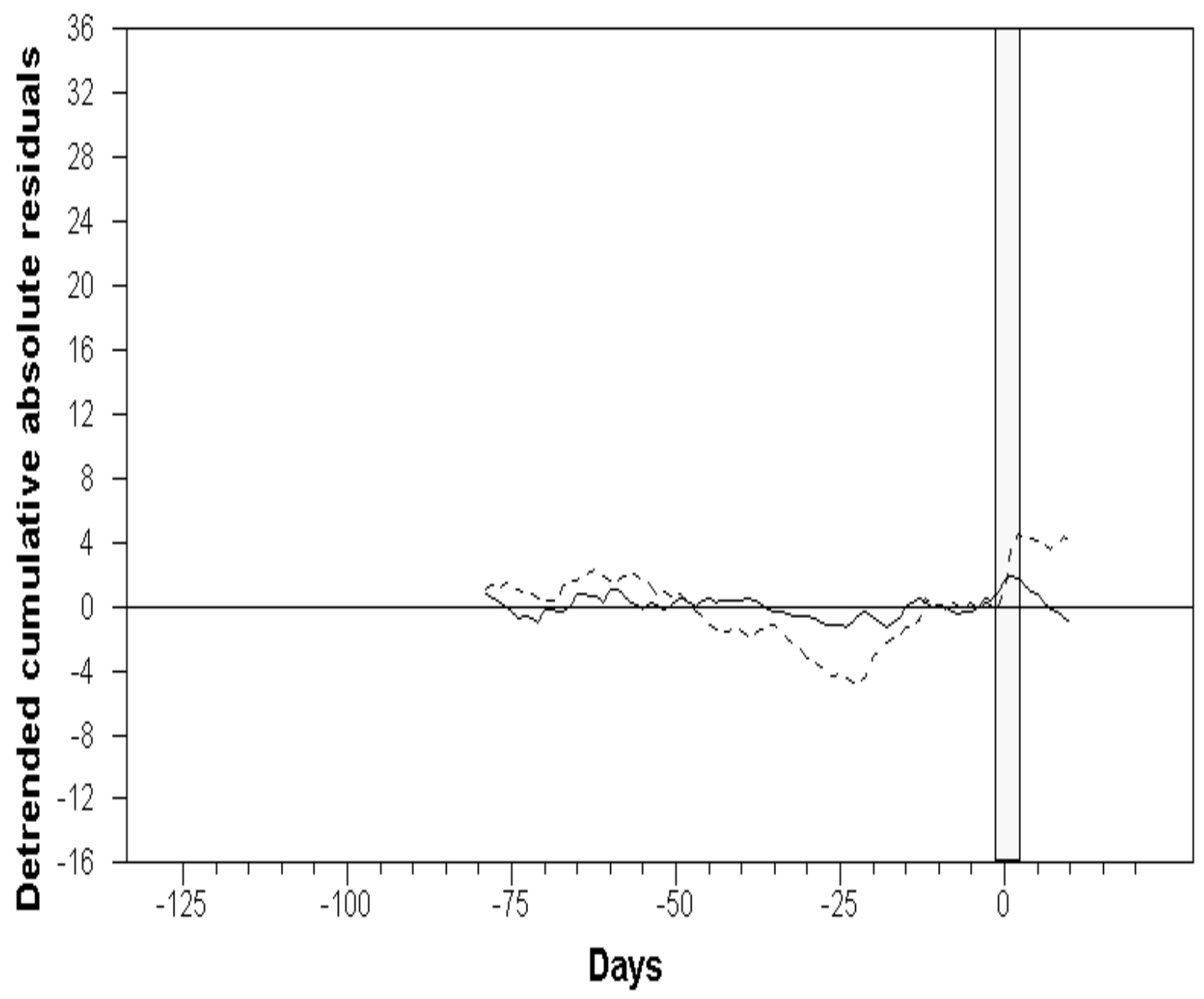

Figure 7. Abnormal returns around corporate announcement for $\mathbf{A}$ and $\mathbf{B}$ shares. For each firm, for each type of share, for each day in an event period $(-80$ to +10$)$, we calculated the absolute value of residuals from a market model of returns. We then averaged the absolute value of residuals over all share types for each day in the event period. We then cumulated through event time, -80 to +10 . Finally, we detrended the series by regressing it on a time trend. The y-axis gives this detrended CAR on day $t$, where t ranges from -80 to +10 . The shaded area in the figure highlights the announcement event window $(-1$ to +2$)$. The solid line represents $A$ shares. The dashed line represents $B$ shares. 